$\mathrm{A} \mathrm{J}_{\mathrm{sin}} \mathrm{H}$

Article history :

Received : 16.01.2013

Revised : 15.03.2015

Accepted : 01.04.2015
Members of the Research Forum

Associated Authors:

${ }^{1}$ Department of Genetics and Plant Breeding, Indira Gandhi Krishi

Vishwavidyalaya, RAIPUR (C.G.)

INDIA

${ }^{2}$ Department of Vegetable Science, Indira Gandhi Krishi

Vishwavidyalaya, RAIPUR (C.G.) INDIA

Author for correspondence : D. SHARMA

Department of Vegetable Science, Indira Gandhi Krishi

Vishwavidyalaya, RAIPUR (C.G.)

INDIA

Email : dsharma_hort@yahoo.co.uk
THEASIAN JOURNALOF HORTICULTURE

Volume 10 | Issue 1 | June, 2015 | 1-10

Visit us -www.researchjournal.co.in

\title{
Early generation selection for green pod yield and its components in vegetable cowpea [Vigna unguiculata (L.) Walp.]
}

\section{SHARMA, N. MEHTA ${ }^{1}$ AND J. SINGH ${ }^{2}$}

ABSTRACT : Correlation and path co-efficient analysis were carried out in parents, $\mathrm{F}_{1}$ and $\mathrm{F}_{2}$ generations of $6 \times 4$ parental line $x$ tester cross in cowpea. Experiment comprising of 60 diverse vegetable cowpea genotypes was carried out at Horticultural research cum instructional farm, Indira Gandhi Krishi Vishwavidyalaya, Raipur during Kharif of 2008. The result of correlation study in all three generations showed that green pod yield per plant had significant and positive correlation with number of pods per plant, pod length and pod weight. In base population, $\mathrm{F}_{1}$ and $\mathrm{F}_{2}$ the path analysis revealed that number of pods per cluster, days to final picking, pod weight and fruiting duration expressed a highest positive direct effect on green pod yield per plant, respectively. The correlation and path analysis studies revealed that 100 seed weight, pod weight, pod length and number of pods per plant were major components of green pod yield in early generations of vegetable cowpea. Hence, the direct selection in form of selection indices based on these component characters would be effective in development of high yielding genotypes of vegetable cowpea.

KEY WORDS : Cowpea, Correlation, Path analysis

HOW TO CITE THIS ARTICLE : Sharma, D., Mehta, N. and Singh, J. (2015). Early generation selection for green pod yield and its components in vegetable cowpea [Vigna unguiculata (L.) Walp.]. Asian J. Hort., 10(1) : 1-10. 